\title{
EFEKTIVITAS PEMBELAJARAN LABORATORIUM BERBASIS PROYEK (PLBP) TERHADAP KREATIVITAS MAHASISWA
}

\author{
M. Zainudin dan Boedy Irhadtanto \\ Program Studi Pendidikan Matematika, IKIP PGRI Bojonegoro \\ e-mail: zain.akhmad@yahoo.com
}

\begin{abstract}
This apparent study is meant to prove the effectiveness of Project based laboratory Learning (PBLL) toward students' creativity in Statistical Method I subject. The research's populations are all second semester students from II-B and II-C. Data collection method used in this research are documentation and test. The research instruments are document and question test. The document in this research is used to determine the sample of the research through equilibrium analysis with the data collected from the students' result of their study in the mathematics for School I for Junior and Senior High School. The test instrument is used to get the data related to students' creativity. The result of this research shows that PBLL is more effective than direct learning to improve students' creativity especially in the subject of Statistical method I.
\end{abstract}

Keywords: Laboratory Based Learning, Students’ Creativity, Statistical I Method

\begin{abstract}
Abstrak : Tujuan dalam penelitian eksperimental semu ini adalah membuktikan efektivitas pembelajaran laboratorium berbasis proyek (PLBP) terhadap kreativitas mahasiswa pada matakuliah metode statistik I. Populasi dalam penelitian ini adalah seluruh mahasiswa yang mengambil matakuliah metode statistik I. Sampel dalam penelitian ini adalah seluruh mahasiswa tingkat II-B dan II-C. Metode pengumpulan yang digunakan adalah metode dokumentasi dan tes. Instrumen dalam penelitian ini adalah dokumen dan soal. Dokumen dalam penelitian ini digunakan untuk penentuan sampel penelitian melalui uji keseimbangan dengan data hasil belajar matakuliah matematika sekolah I materi statistika untuk SMP dan SMA. Instrumen soal digunakan untuk mengambil data tentang kreativitas mahasiswa. Hasil penelitian ini adalah pembelajaran berbasis laboraturium lebih efektif daripada pembelajaran langsung terhadap kreativitas mahasiswa pada matakuliah metode statistik I.
\end{abstract}

Kata Kunci: Pembelajaran Berbasis Laboratorium, Kreativitas Mahasiswa, Metode Statistik I

\section{PENDAHULUAN}

Salah satu ilmu yang mempelajari cara pengolahan data penelitian adalah statistika. Statistika adalah pengetahuan yang berhubungan dengan cara penyusunan data, penyajian data, dan penarikan kesimpulan mengenai suatu keseluruhan (yang disebut populasi) berdasarkan data yang ada pada bagian dari keseluruhan tadi atau yang disebut sampel (Budiyono, 2009: 2). Metode statistik adalah prosedur-prosedur yang digunakan dalam pengumpulan, penyajian, analisis, dan penafsiran (Ronald, 1995: 2).
Metode Statistika I merupakan salah satu matakuliah yang wajib ditempuh oleh mahasiswa program studi pendidikan Matematika Fakultas Pendidikan Matematika dan Ilmu Pengetahuan Alam IKIP PGRI Bojonegoro. Matakuliah metode statistik I untuk semester IV program studi pendidikan matematika ini meliputi subyek penelitian, data dan penyajiannya, ukuran gejala pusat, momen, kemiringan, dan kurtosis, distribusi data, regresi dan korelasi. Standar kompetensi setelah selesai mengikuti perkuliahan Metode Statistika I ini mahasiswa semester IV Program Studi Pendidikan 
Matematika Fakultas Pendidikan MIPA diharapkan dapat mengaplikasikan statistik deskriptif dalam penelitian pendidikan sesuai dengan kaidah yang berlaku.

Berdasarkan hasil evaluasi perkuliahan pada ujian akhir semester genap matakuliah Metode Statistika I tahun akademik 2014/ 2015, rerata hasil belajar mahasiswa semester IV sebesar 59,56 dan sebanyak $70 \%$ mahasiswa memperoleh nilai di bawah 80. Rerata hasil belajar mahasiswa pada matakuliah Metode Statistika I masih dikategorikan rendah karena masih di bawah Kriteria Ketuntasan Minimal (80).

Rendahnya rata-rata hasil belajar matakuliah Metode Statistika I, ada kemungkinan dipengaruhi oleh komponen dari dalam (mahasiswa) dan dari luar. Berdasarkan evaluasi proses pembelajaran pada matakuliah Metode Statistika I tahun akademik 2014/2015, didapat simpulan antara lain, aktivitas mahasiswa dalam pembelajaran tergolong rendah. Rendahnya aktivitas belajar mahasiswa karena model pembelajaran yang digunakan dosen adalah model pembelajaran langsung. Materi perkuliahan Metode Statistik I diberikan kepada mahasiswa dalam bentuk jadi dan kurang melibatkan mahasiswa secara aktif dalam menelaah, menganalisis, dan menyimpulkan konsep dasar statistika sehingga pengalaman belajar mahasiswa dapat dikatakan belum maksimal.

Pembelajaran matakuliah Metode Statistika I yang belum melibatkan mahasiswa secara maksimal sebagai kemungkinan penyebab rendahnya kemampuan mahasiswa mengaplikasikan statistika harus diperbaiki dengan pembelajaran yang memberikan pengalaman belajar yang menarik dan bermakna bagi mahasiswa. Hal itu dikarenakan pada matakuliah statistika tidak hanya diperlukan pengetahuan tentang konsep, tetapi juga diperlukan kemampuan berpikir kritis mahasiswa dalam pengolahan data penelitian.

Berpikir kritis dapat diartikan sebagai suatu kombinasi dari berpikir logis dan berpikir divergen yang didasarkan pada intuisi tetapi masih dalam kesadaran (Pehkonen, 1997). Hasil berpikir kreatif seseorang dapat disebut dengan kreativitas berupa kemampuan menghasilkan sesuatu (soal, masalah atau pengetahuan) yang pada dasarnya baru dan sebelumnya tidak dikenal oleh pembuatnya serta berbeda dari sesuatu (soal, masalah atau pengetahuan) lain yang dibuat berdasar sebuah informasi. kreativitas ditinjau dari berdasar kefasihan (fluency), fleksibilitas dan kebaruan (orisinilitas). Berpikir kreatif merupakan kegiatan mental untuk menemukan "ide baru" yang sesuai dengan tujuan, dengan cara mensintesis ideide, membangun (generating) ide-ide, dan menerapkannya (Siswono, 2008: 10).

Silver (1997) menjelaskan bahwa untuk menilai berpikir kreatif anak-anak dan orang dewasa sering digunakan "The Tourence Test of Creative Thingking (TTCT)". Tiga komponen kunci yang dinilai dalam kreativitas menggunakan TTCT adalah kefasihan (fluency), fleksibilitas dan kebaruan (orisinilitas). Kefasihan mengacu pada banyaknya ide-ide yang dibuat dalam merespon sebuah perintah. Fleksibilitas tampak pada perubahan-perubahan pendekatan ketika merespon perintah. Kebaruan merupakan keaslian ide yang dibuat dalam merespon perintah. Mahmudi (2010), menyatakan bahwa salah satu cara mengukur kemampuan berpikir kreatif adalah dengan soal terbuka (open ended), yaitu soal yang memiliki beragam solusi atau strategi penyelesaian. Hasil dari berpikir kreatif sering disebut kreativitas. Kreativitas merupakan kemampuan seseorang menghasilkan sesuatu (soal, masalah atau pengetahuan) yang pada dasarnya baru dan sebelumnya tidak dikenal 
oleh pembuatnya serta berbeda dari sesuatu (soal, masalah atau pengetahuan) lain yang dibuat berdasar sebuah informasi. kreativitas ditinjau dari berdasar kefasihan (fluency), fleksibilitas dan kebaruan (orisinilitas). Salah satu penilaian kreativitas mahasiswa dapat dilakukan melalui acuan yang dibuat Silver (1997: 78) yang meliputi kefasihan, fleksibilitas, dan kebaruan, sebagai berikut

Tabel 1. Komponen Kreativitas dan Pemecahan Masalah

\begin{tabular}{ll}
\hline \multicolumn{1}{c}{ Pemecahan Masalah } & Komponen Kreativitas \\
\hline $\begin{array}{l}\text { Mahasiswa menyelesaikan masalah dengan } \\
\text { bermacam-macam interpretasi solusi }\end{array}$ & Kefasihan \\
\hline $\begin{array}{l}\text { Mahasiswa menyelesaikan (atau menyatakan atau } \\
\text { justifikasi) dengan satu cara, kemudian dengan cara } \\
\text { lain mahasiswa mendiskusikan berbagai metode } \\
\text { penyelesaian }\end{array}$ & Fleksibilitas \\
\hline $\begin{array}{l}\text { Mahasiswa memeriksa jawaban dengan berbagai } \\
\text { metode penyelesaian dan kemudian membuat } \\
\text { metode yang baru yang berbeda. }\end{array}$ & Kebaruan \\
\hline
\end{tabular}

Kreativitas dalam penelitian ini adalah kemampuan mahasiswa dalam mengolah data yang berbeda dengan karya tulis yang sudah ada dan kemungkinan pemecahan masalah melalui alternatif-alternatif inovatif yang dipaparkan melalui desain penelitian kuantitatif dengan bahasa yang baku serta memenuhi kaidah yang berlaku.

Proses pembelajaran melibatkan aktivitas yang kompleks, bukan sekedar transfer of knowledge dari pendidik kepada peserta didik secara tekstual. Dalam setiap pembelajaran, harus diupayakan untuk dapat mengantarkan peserta didik pada penguasaan kompetensi yang dicanangkan, termasuk nilai-nilai dan sikap yang melandasinya. Oleh karena itu pembelajaran tidak harus selalu dilaksanakan di kelas. Adakalanya pembelajaran harus dilaksanakan di laboratorium atau di lapangan. Dalam hal ini tentu diperlukan strategi dan keterampilan yang berbeda. Pembelajaran pada matakuliah statistika ini diharapkan dapat mengoptimalkan kreativitas melalui keterlibatan mahasiswa secara penuh dalam pengalaman belajar. Salah satu model pembelajaran yang memberikan kesempatan mahasiswa berpikir kreatif melalui pengalaman belajar adalah Pembelajaran Laboratorium Berbasis Proyek (PLBP).

Laboratorium secara umum dipahami sebagai suatu sarana atau gedung yang dirancang khusus untuk melaksanakan pengukuran, penetapan, dan pengujian untuk keperluan penelitian ilmiah dan praktik pembelajaran (Rahayuningsing dan Dwiyanto, 2005). Tetapi, akhir-akhir ini analog dengan batasan itu berbagai disiplin ilmu pengetahuan sering menganggap (claim) bahwa lapangan tempat mereka bekerja dan melakukan penelitian juga dianggap sebagai laboratorium, sehingga disebut dengan laboratorium lapangan.

Laboratorium merupakan tempat untuk mengaplikasikan teori keilmuan, pengujian teoritis, pembuktian uji coba, penelitian, dan sebagainya dengan menggunakan alat bantu yang menjadi kelengkapan dari sarana dan prasarana dengan kuantitas dan kualitas memadai (Depdiknas, 2002: 26).

Prinsip dasar pembelajaran di laboratorium adalah mahasiswa belajar sendiri dan saling belajar dengan mahasiswa lain dalam tim. Meskipun secara prinsip dalam pembelajaran di laboratorium mahasiswa belajar 
dengan cara mereka sendiri, tetapi dosen menyediakan percobaan, tugas, instruksi, dan petunjuk pelaksanaan (Rahayuningsing dan Dwiyanto, 2005).

Pembelajaran pada matakuliah metode statistika I ini diharapkan dapat mengoptimalkan kreativitas melalui keterlibatan mahasiswa secara penuh dalam pengalaman belajar. Salah satu model pembelajaran yang memberikan kesempatan mahasiswa berpikir kreatif melalui pengalaman belajar adalah Pembelajaran laboratorium.

Kelemahan pembelajaran laboratorium yang dikarenakan petunjuk praktikum yang terlalu rinci yang berakibat pada kurang merangsang peserta didik untuk mengembangkan daya nalarnya untuk merencanakan dan menyelesaikan persoalan yang dihadapinya, sehingga kreativitas peserta didik tidak dapat berkembang secara optimal perlu dimodifikasi melalui pemberian kesempatan kepada mahasiswa untuk berkreasi dalam dalam mengaplikasikan konsep.

Pemberian kesempatan mahasiswa untuk berkreativitas dalam mengaplikasikan konsep dalam pembelajaran laboratorium tanpa terikat petunjuk pratikum dapat diberikan melalui kerja proyek. Model pembelajaran yang memberikan kesempatan kepada pendidik untuk mengelola pembelajaran dengan melibatkan kerja proyek disebut dengan model pembelajaran berbasis proyek (Widyantini, 2014). Kerja proyek memuat tugas-tugas yang kompleks berdasarkan permasalahan (problem) yang diberikan kepada mahasiswa sebagai langkah awal dalam mengumpulkan dan mengintegrasikan pengetahuan baru berdasarkan pengalamannya dalam beraktivitas secara nyata, dan menuntut mahasiswa untuk melakukan kegiatan merancang, melakukan kegiatan investigasi atau penyelidikan, me- mecahkan masalah, membuat keputusan, serta memberikan kesempatan kepada siswa untuk bekerja secara mandiri maupun kelompok (kolaboratif).

Pembelajaran laboratorium berbasis proyek dalam penelitian yang akan dilakukan merupakan proses pembelajaran yang melibatkan tempat riil (lapangan) sebagai tempat mendapatkan data penelitian untuk diolah dan digunakan sebagai dasar membuktikan hipotesis penelitian.

Proses pembelajaran secara langsung dalam dunia riil dapat memberikan pengalaman nyata pada mahasiswa, artinya pengalaman itu akan semakin kongkret, sehingga mahasiswa akan terhindar dari kesalahan persepsi dari pembahasan materi pelajaran tertentu. Pembelajaran laboratorium dalam penelitian yang akan dilakukan merupakan proses pembelajaran yang melibatkan tempat riil sebagai tempat mendapatkan data penelitian untuk diolah dan digunakan sebagai dasar membuktikan hipotesis penelitian. Tujuan dari penelitian ini untuk membuktikan efektivitas model pembelajaran laboratorium berbasis proyek terhadap kreativitas mahasiswa dalam matakuliah Metode Statistik I.

\section{METODE}

Penelitian ini merupakan penelitian eksperimen kuasi yang difokuskan pada penggunaan pembelajaran laboratorium pembelajaran berbasis proyek metode statistika I. Rancangan penelitian ini menggunakan The Matching Statis Group Comparison Design (rancangan statis dengan pemadanan). Pada rancangan ini, tes awal tidak digunakan. Namun demikian, jika skor tes awal tentang variabel terikat sudah ada, skor tersebut dapat dipakai untuk memadankan subjek dengan efektif. Kedua ukuran ini dijajarkan sehingga skor anggota- 
anggota yang saling berhadapan sedapat mungkin saling mendekati. Selanjutnya salah satu anggota dari setiap pasangan itu secara acak diberi salah satu perlakuan, sebagai kelompok eksperimental (Budiyono, 2003: 92).

Populasi penelitian adalah mahasiswa pendidikan matematika FPMIPA IKIP PGRI Bojonegoro Tahun Akademik 2015/2016. Sampel dalam penelitian ini adalah mahasiswa program studi pendidikan matematika FPMIPA IKIP PGRI Bojonegoro semester IV yang mengambil matakuliah metode statistika I Tahun Akademik 2015/2016. Teknik sampling yang digunakan adalah cluster random sampling yaitu sistem penyampelan yang didasarkan atas kelas. Sampel penelitian tersebar dalam dua kelas. Satu kelas dipilih sebagai kelas eksperimen, dan kelas lainnya merupakan kelas kontrol.

Prosedur yang ditempuh dalam penelitian ini meliputi studi pendahuluan dan studi literatur, persiapan, implementasi, analisis data dan penyusunan laporan. Analisis data dilakukan terhadap skor kemampuan awal dan skor akhir meliputi:

\section{a. Uji Normalitas Distribusi Data}

Asumsi normalitas merupakan prasyarat bagi prosedur statistika inferensial. Asumsi normalitas dieksplorasi menggunakan uji normalitas lilifors dengan taraf signifikansi $\alpha=0,05$. Dalam pengujian hipotesis, kriteria untuk menolak atau tidak menolak $\mathrm{H}_{0}$ berdasarkan nilai lilifors hitung adalah $H_{0}$ ditolak jika $L \in D K$ atau $H_{0}$ tidak ditolak jika $L \notin D K$ (Budiyono, 2009: 170).

\section{b. Uji Homogenitas}

Apabila diketahui data berdistribusi normal, maka langkah selanjutnya adalah melakukan uji homogenitas varian (variance) dengan uji bartlet. Uji hipotesis bartlet digunakan untuk mengetahui apakah varian kedua kelompok data sama besar terpenuhi atau tidak terpenuhi. Dasar pengambilan keputusan, jika nilai $\chi^{2}$ hitung $\geq$ $\chi^{2}$ tabel maka $\mathrm{H}_{0}$ ditolak sedangkan jika $\chi^{2}$ hitung $<\chi^{2}$ tubel maka $\mathrm{H}_{0}$ diterima.

\section{c. Uji Keseimbangan}

Uji keseimbangan bertujuan untuk mengetahui kemampuan dari kelas eksperimen dan kelas kontrol dalam keadaan seimbang atau tidak. Data yang digunakan untuk uji keseimbangan adalah nilai ujian matakuliah matematika sekolah I pada materi statistika. Uji keseimbangan dalam penelitian ini menggunakan uji t dua pihak.

\section{d. Uji Hipotesis}

Berdasarkan hasil uji normalitas data, bila data berdistribusi normal maka uji perbandingan dua rerata akan dilakukan menggunakan uji parametrik yaitu uji $\mathrm{t}$ dua sampel independen, tetapi apabila data tidak berdistribusi normal maka uji hipotesis akan dilakukan menggunakan uji non parametrik. Uji hipotesis ini dilakukan dengan taraf signifikansi $\alpha=0,05$. Rumusan hipotesis statistik pada penelitian ini adalah sebagai berikut:

$$
\begin{aligned}
& H_{0}: \mu_{1} \leq \mu_{2} \\
& H_{1}: \mu_{1}>\mu_{2}
\end{aligned}
$$

dimana, $\mathrm{H}_{0}$ adalah hipotesis yang menyatakan rerata skor kreativitas mahasiswa pada pembelajaran laboratorium tidak lebih baik daripada rerata skor kreativitas mahasiswa pada pembelajaran langsung dan $\mathrm{H}_{1}$ adalah hipotesis yang menyatakan rerata skor kreativitas mahasiswa pada pembelajaran laboratorium lebih baik daripada rerata skor kreativitas mahasiswa pada pembelajaran langsung. Dalam pengujian hipotesis, kriteria untuk menolak atau tidak menolak $\mathrm{H}_{0}$ 
berdasarkan nilai t tabel adalah jika $\mathrm{H}_{1}$ diterima jika $t_{\text {hitung }}<\mathrm{t}_{\text {tabel }}$ dan $\mathrm{H}_{1}$ ditolak jika $t_{\text {hitung }}>t_{\text {tabel. }}$.

\section{HASIL DAN PEMBAHASAN}

Pengujian efektivitas pembelajaran laboratorium berbasis proyek terhadap kreativitas mahasiswa pada mata kuliah metode statistik I dilakukan dengan membandingkan nilai rerata kreativitas hasil belajar pada matakuliah metode statistik I antara kelas eksperimen yang menggunakan pembelajaran laboratorium berbasis proyek dengan kelas kontrol yang menggunakan model pembelajaran langsung (direct instruction). Data tentang kemampuan awal dan kreativitas nilai rerata tes awal dan tes akhir antara kelas eksperimen dan kelas kontrol ditunjukkan pada tabel 2 .

Tabel 2. Rerata Kemampuan Awal dan Akhir Kelas Eksperimen dan Kontrol

\begin{tabular}{lcc}
\hline \multirow{3}{*}{ Kelas } & Rerata & Rerata \\
& Kemampuan & Kemampuan \\
& Awal & Akhir \\
\hline Eksperimen & 72,34 & 85,952 \\
Kontrol & 70,13 & 81,143 \\
\hline
\end{tabular}

Data kemampuan awal diambil pada nilai matakuliah matematika sekolah I pokok bahasan statistika SMP dan SMA. Data kemampuan awal dianalisis guna melakukan uji kesimbangan. Uji keseimbangan dilakukan dengan menggunakan uji t dua pihak dengan pra syarat analisis, yakni uji normalitas dan homogenitas. Hasil uji keseimbangan dalam penelitian ini adalah:

\section{a. Uji Normalitas}

Uji normalitas dilakukan dengan menggunakan metode liliefors. Berdasarkan uji normalitas dengan metode liliefors pada kelas eksperimen diperoleh $L_{o b s}=0,080031$ dan $L_{\text {tabel }}=0,156624$, karena $L_{o b s}<$ $L_{\text {tabel }}$, maka $\mathrm{H}_{0}$ diterima, sehingga disimpulkan sampel berasal dari populasi yang berdistribusi normal. Berdasarkan uji nor- malitas dengan metode lilifors pada kelas kontrol diperoleh $L_{o b s}=0,078110$ dan $L_{\text {tabel }}=0,156624$, karena $L_{\text {obs }}<L_{\text {tabel }}$, maka $\mathrm{H}_{2}$ diterima, sehingga disimpulkan sampel berasal dari populasi yang berdistribusi normal.

\section{b. Uji Homogenitas}

Berdasarkan uji homogenitas dengan metode bartlet, diperoleh data $\chi_{\text {hitung }}^{2}=$ 2,1955 dan $\chi_{\text {hitung }}^{2}=3,841$, karena $\chi^{2}$ hitung $<\chi^{2}$ tabel maka $\mathrm{H}_{0}$ diterima, sehingga disimpulkan bahwa variansi kedua populasi sama, dengan kata lain dapat dinyatakan bahwa kedua populasi memiliki variansi yang homogen.

\section{c. Uji Keseimbangan}

Berdasarkan hasil analisis uji keseimbangan dengan uji t dua pihak didapat, $t_{\text {hitung }}=1,014089$ dan $t_{0,025: 62}=1,96$ (DK= $\{t \mid t<-1,96$ atau $t>1,96\}$, akibatnya thitung $\notin D K$, sehingga disimpulkan bahwa sampel memiliki kemampuan awal yang sama.

Data kreativitas mahasiswa pada matakuliah metode statistika I digunakan untuk menentukan efektivitas penggunaan pembelajaran laboratorium berbasis proyek. Data kreativitas tersebut terdiri dari kefasihan, fleksibilitas, dan kebaruan. Kefasihan dalam matakuliah metode statistika I ini meliputi kemampuan mahasiswa menyelesaikan masalah dengan bermacam-macam interpretasi solusi. Fleksibilitas yang dimaksud dalam penelitian ini adalah kemampuan mahasiswa menyelesaikan (atau menyatakan atau justifikasi) dengan satu cara, kemudian dengan cara lain mahasiswa mendiskusikan berbagai metode penyelesaian. Kebaruan dalam penelitian ini adalah kemampuan mahasiswa memeriksa jawaban dengan berbagai metode penyelesaian dan 
kemudian membuat metode yang baru yang berbeda. Masalah dalam perkuliahan metode statistik I berkaitan dengan subyek penelitian, data dan penyajiannya, ukuran gejala pusat, momen, kemiringan, dan kurtosis, distribusi data, regresi dan korelasi.

Analisis data tentang kreativitas mahasiswa dilakukan menggunakan uji-t pihak kanan dengan prasyarat normalitas dan homogenitas. Hasil uji hipotesis yang dilakukan pada data kreativitas dalam penelitian ini adalah:

\section{a. Uji Normalitas}

Uji normalitas dilakukan dengan menggunakan metode liliefors. Berdasarkan uji normalitas dengan metode liliefors pada kelas eksperimen diperoleh $L_{\text {obs }}=0,134369$ dan $L_{\text {tabel }}=0,156624$, karena $L_{\text {obs }}<$ $L_{\text {tabel }}$, maka $\mathrm{H}_{0}$ diterima, sehingga disimpulkan sampel berasal dari populasi yang berdistribusi normal. Berdasarkan uji normalitas dengan metode lilifors pada kelas kontrol diperoleh $L_{o b s}=0,153069$ dan $L_{\text {tabel }}=0,156624$, karena $L_{\text {obs }}<L_{\text {tabel }}$, maka $\mathrm{H}_{2}$ diterima, sehingga disimpulkan sampel berasal dari populasi yang berdistribusi normal.

\section{b. Uji Homogenitas}

Berdasarkan uji homogenitas dengan metode bartlet, diperoleh data $\chi_{\text {hitung }}^{2}=$ 0,9354 dan $\chi_{\text {hitung }}^{2}=3,841$, karena $\chi^{2}$ hitung $<\chi^{2}$ tabel maka $\mathrm{H}_{0}$ diterima, sehingga disimpulkan bahwa variansi kedua populasi sama, dengan kata lain dapat dinyatakan bahwa kedua populasi memiliki variansi yang homogen.

\section{c. Uji Hipotesis}

Berdasarkan hasil analisis uji hipotesis dengan uji-t dua pihak didapat, $t_{\text {hitung }}=$ 2,909873 dan $t_{0,05 ; 62}=1,998971 \quad(\mathrm{DK}=$ $\{t \mid t>998971\}$, akibatnaya $t_{\text {hitung }} \in D K$, sehingga $\mathrm{H}_{0}$ ditolak dan dapat disimpulkan bahwa pembelajaran laboratorium berbasis proyek lebih efektif daripada pembelajaran langsung terhadap kreativitas mahasiswa.

Berdasarkan hasil analisis data kemampuan awal statistika, diketahui bahwa skor rata-rata kelas kontrol cenderung sama dengan kelas eksperimen sebelum penerapan pembelajaran laboratorium berbasis proyek. Berdasarkan analisis data dengan uji-t dua pihak dapat disimpulkan bahwa kedua kelas memiliki kemampuan awal yang sama. Hal ini disebabkan karena beberapa konsep statistika sudah dipelajari mahasiswa pada matapelajaran matematika di jenjang SMP dan SMA, sehingga pada matakuliah matematika sekolah I pokok bahasan statistika SMP dan SMA tidak banyak menemui kendala. Kedua kelompok kelas diberi perlakuan pembelajaran yang berbeda yaitu kelas kontrol menggunakan pembelajaran langsung sedangkan kelas eksperimen menggunakan pembelajaran laboratorium berbasis proyek.

Berdasarkan hasil analisis data, mahasiswa yang mendapatkan pembelajaran dengan pembelajaran laboratorium berbasis proyek secara keseluruhan menunjukkan memiliki kreativitas lebih baik disbandingkan dengan mahasiswa yang mendapatkan pembelajaran dengan pembelajaran langsung. Mahasiswa dalam kelas eksperimen diarahkan dengan berbagai aktifitas untuk mengkonstruksikan berbagai konsep serta mengaplikasikan dalam pengalaman sehari-hari terkait subyek penelitian, data dan penyajiannya, ukuran gejala pusat, momen, kemiringan, dan kurtosis, distribusi data, regresi dan korelasi.

Hasil temuan tersebut sesuai dengan model yang dikembangkan oleh Ferani (2005) yang menyatakan bahwa pembelajaran laboratorium berbasis proyek ini ber- 
tujuan: a) mengkonfrontasi konsep awal mereka dengan bagaimana alam bekerja; (b) melatih skill problem solving; (c) belajar menggunakan alat; (d) belajar mendesain ekperimen; (e) mengobservasi sebuah peristiwa yang memerlukan penjelasan yang tidak mudah sehingga mereka menyadari bahwa diperlukan ilmu untuk menjawabnya; (f) mendapatkan apresiasi kesulitan dan kegembiraan saat melakukan eksperimen; (g) mengalami pengalaman seperti ilmuwan asli; dan (h) merasa senang melakukan kegiatan yang lebih aktif daripada duduk dan mendengarkan.

Bila seorang anak selama belajar hanya diberi informasi tentang statistika yang sudah ada dengan cara mendengarkan penjelasan dosen, maka statistika itu sendiri akan berhenti berkembang. Statistika bukan hanya pengetahuan yang terdiri dari faktafakta, prinsip-prinsip, konsep-konsep dan teori-teori, melainkan juga keterampilanketerampilan dalam mengaplikasikannya. Hal ini sesuai yang dikemukan oleh Bay, M. et al (1992) yaitu siswa tidak dipandang sebagai penerima informasi yang pasif, tetapi sebagai peserta belajar yang aktif dalam proses penguasaan pengetahuan.

Bruce Weil (1980), mengemukakan tiga prinsip penting dalam proses pembelajaran, yakni: pertama, proses pembelajaran adalah membentuk kreasi lingkungan yang dapat membentuk atau merubah struktur kognitif siswa. Tujuan pengaturan lingkungan ini dimaksudkan untuk menyediakan pengalaman belajar yang memberi latihan-latihan penggunaan fakta-fakta. Menurut Piaget, struktur kognitif akan tumbuh manakala peserta didik memiliki pengalaman belajar. Oleh karena itu proses pembelajaran menuntut aktivitas peserta didik secara penuh untuk mencari dan menemukan sendiri.

Kedua, berhubungan dengan tipetipe pengetahuan yang harus dipelajari. Ada tiga tipe pengetahuan yang masing-masing memerlukan situasi yang berbeda dalam mempelajarinya. Pengetahuan tersebut adalah pengetahuan fisis, sosial dan logika. Pengetahuan fisis adalah pengetahuan akan sifatsifat fisis dari suatu objek atau kejadian seperti bentuk, besar, berat, serta bagaimana objek itu berinteraksi satu dengan yang lainnya. Pengetahuan fisis diperoleh melalui pengalaman indra secara langsung. Misalkan peserta didik menimbang berat badan anak usia sekolah dasar. Dari tindakantindakan langsung itulah anak membentuk struktur kognitif tentang berat badan anak usia sekolah dasar.

Pengetahuan sosial berhubungan dengan perilaku individu dalam suatu sistem sosial atau hubungan antara manusia yang dapat mempengaruhi interaksi sosial. Contoh pengetahuan tentang aturan, hukum, moral, nilai, bahasa dan lain sebagainya. Pengetahuan tentang hal di atas, muncul dalam budaya tertentu sehingga dapat berbeda antara kelompok yang satu dengan yang lain. Pengetahuan sosial tidak dapat dibentuk dari suatu tindakan seseorang terhadap suatu objek, tetapi dibentuk dari interaksi seseorang dengan orang lain. Ketika anak melakukan interaksi dengan temannya, maka kesempatan untuk membangun pengetahuan sosial dapat berkembang (Wadsworth, 1989).

Pembelajaran berbasis laboraturium memberikan kesempatan kepada peserta didik untuk belajar secara holistik. Hal tersebut sejalan dengan empat pilar pendidikan universal seperti yang dirumuskan Unesco (1996) yaitu (1) learning to know, yang berarti juga learning to learn, (2) learning to do, (3) learning to be, dan (4) learning to live together. Learning to know atau learning to learn mengandung pengertian bahwa itu pada dasarnya tidak hanya berorientasi kepada produk atau hasil 
belajar, akan tetapi juga harus berorientasi kepada proses belajar. Learning to do, mengandung pengertian bahwa belajar itu bukan hanya sekedar mendengar dan melihat dengan tujuan akumulasi pengetahuan, akan tetapi belajar untuk berbuat dengan tujuan akhir penguasaan kompetensi yang sangat diperlukan dalam era persaingan global. Kompetensi akan dimiliki manakala anak diberi kesempatan untuk melakukan sesuatu. Dengan demikian learning to do juga berarti proses pembelajaran berorientasi kepada pengalaman (learning by experiences). Learning to be, mengandung pengertian bahwa belajar adalah membentuk manusia yang "menjadi dirinya sendiri", dengan kata lain belajar untuk mengaktualisasikan dirinya sendiri sebagai individu dengan kepribadian yang memiliki tanggung jawab sebagai manusia. Learning to live together, adalah belajar untuk bekerjasama. Hal ini sangat diperlukan sesuai dengan tuntutan kebutuhan dalam masyarakat global di mana manusia baik secara individual mau-

\section{DAFTAR PUSTAKA}

Bay, M. et al. 1992. Science Instructional for the Mildly Handicapped Direc Instruction versus Discovery Teaching: Journal of Research in Science Teaching 29 (7). 555.

Budiyono. 2003. Metodologi Penelitian Pendidikan. Surakarta: UNS Press.

Budiyono. 2009. Statistika untuk Penelitian. Surakarta: UNS Press.

Feranie, S. 2005. Peningkatan Daya Guna Praktikum Fisika Dasar melalui Penataan Ulang Petunjuk/Panduan Praktikum, Seting Pelaksanaan serta Prosedur Penilaian Praktikum. Laporan Penelitian, Bandung: Jurdik Fisika: Tidak diterbitkan. pun secara kelompok tidak mungkin dapat hidup sendiri atau mengasingkan diri bersama kelompoknya.

Pembelajaran laboratorium berbasis proyek memberikan fasilitas kepada mahasiswa dalam mengaplikasikan statistika dalam permasalahan sehari-hari, sehingga pembelajaran lebih bermakna. Hal ini sejalan dengan pendapat Railsback (2002) yang menyatakan bahwa Pembelajaran Berbasis Projek (PBP) merupakan pembelajaran otentik yang memfasilitasi mahasiswa dalam merencanakan, melaksanakan, melaporkan, dan mengevaluasi proyek yang dapat diterapkan dalam kehidupan sehari-hari.

\section{SIMPULAN}

Berdasarkan hasil dan pembahasan maka disimpulkan bahwa pembelajaran menggunakan pembelajaran laboratorium berbasis proyek secara signifikan lebih efektif dibandingkan dengan mahasiswa yang mengikuti pembelajaran menggunakan pembelajaran langsung.

Joyce, B. and Weil, M. 1980. Models of Teaching (Second Edition). Englewood Cliffs, New Jersey: Prentice-Hall, Inc.

Pehkonen, Erkki. 1997. The State-of Art in Mathematical Creativity. Vol. 29, No. 3, 230-245.

Rahayuningsing, E. dan Dwiyanto, Djoko. 2005. Pembelajaran di Laboratorium. Yogyakarta: UGM Press.

Railsback, J. (2002). Project-Basic Learning: Creating Excitemen for Learning. Northwest Regional Educational Laboratory.

Ronald E.. 1995. Pengantar Statistik Edisi 3 Alih Bahasa: Bambang Sumantri. Jakarta: Gramedia Pustaka Utama. 
Silver, E.A. 1997. Fostering Creativity Through Instruction Rich in Mathematical Problem Solving and Thinking in Problem Posing. Vol. 29, No. 3, 237-289.

Siswono, T. Y. 2008. Kumpulan Karya 2005-2007. Surabaya: UNESA Press.
Widyantini, T. 2014. Penerapan Model Project Based Learning.(online) http://p4tkmatematika.org/file/ARTIKE L/Artikel\%20Matematika/Penerapan\% 20Model\%20Project\%20Based\%20Lea rning.pdf, 2 Januari 2015. 